\author{
Research Article \\ www.ijrap.net
}

\title{
ANALYTICAL STUDY ON SHODHANA OF JAYAPALA
}

Sujatha $K^{1 *}$, Revanasiddappa S. Sarashetti ${ }^{2}$, Swetha $\mathrm{S}^{3}$

${ }^{1}$ Associate Professor, Department of Rasashastra and Bhaishjya Kalpana, S. D. M. College of Ayurveda, Udupi, Karnataka, India

${ }^{2}$ Professor and Head, P. G. Department of Rasashastra and Bhaishajya Kalpana, BLDEA'S AVS PGCRC Ayurveda Mahavidyalaya, Bijapur, Karnataka, India

${ }^{3}$ P.G. Scholar, Department of Rasashastra and Bhaishjya Kalpana, S. D. M. College of Ayurveda, Udupi, Karnataka, India

Received on: 10/07/13 Revised on: 17/10/13 Accepted on: 21/10/13

\author{
*Corresponding author \\ E-mail: sujathanetra@gmail.com \\ DOI: $10.7897 / 2277-4343.04605$ \\ Published by Moksha Publishing House. Website www.mokshaph.com \\ All rights reserved.
}

\section{ABSTRACT}

Ayurveda the life science uses plant, animal and mineral origin drugs in various therapeutics. The science is expertise in the usage of visha drvayas (poisonous drugs) in therapeutics by subjecting them to a samskara known as shodhana. The role played by shodhana procedure in reducing the toxicity of the visha dravya has to be understood in a scientific way. Therefore understanding the role of shodhana of visha dravyas is the need for the hour. In the present study, the Jayapala, one of the upavisha dravyas was subjected to shodhana process and analytical study was carried out to notice the changes before and after shodhana. The study revealed that there is significant role played by the media used for shodhana.

Keywords: Upavisha dravya, Jayapala, Shodhana, Analytical study

\section{INTRODUCTION}

Human being is the most superior animal on the earth because of his intellect. He has been involved in the continuous process of discovery and inventions since ages. It is this effort which has led to the development of many wonderful concepts like shodhana. Rasashastra has propounded the use of visha dravyas in therapeutics. Detailed description is found in classical texts regarding the different shodhana procedures to be adopted for the visha dravyas before their usage in medicines. Jayapala is one of the upavisha dravyas ${ }^{1}$ and in all the references it's been told that shodhana has to be done only after removing the radicle (ankura) ${ }^{2}$. Present study aims at analysing the role played by the shodhana procedure and the radicle in the process of shodhana of Jayapala.

\section{MATERIALS AND METHODS}

\section{Pharmaceutical source}

Authenticated raw drug was collected from market and purification was done in SDMCA Udupi at Rasashastra practical laboratory.

\section{Materials required}

Vessels, gloves, cotton cloth, gas stove, mortar and pestle, new earthen plates.

\section{Ingredients and quantity}

Ashuddha Jayapala seeds - 1000 g, Milk - 4 litres

\section{Procedure of Jayapala shodhana \\ Method 1}

Ashuddha Jayapala seeds were cleaned to remove the physical impurities and then washed with water and dried in shade for a day. After complete drying, the seed coat was removed wearing gloves to hands. Then the cotyledons were separated carefully to remove the radicle. The seeds were tied into pottali using a clean white cotton cloth. Then it was subjected to swedana using milk in dolayantra for 3 hours. After 3 hours of swedana, pottali was untied, the seeds were washed with hot water, and then it was grinded in mortar. Grinded material was smeared on new earthen plates in a thin layer and kept for drying in sunlight. After complete drying shuddha Jayapala was collected and stored in an air tight container. Gloves were used throughout the procedure ${ }^{2}$.

\section{Method 2}

The same procedure was carried out to another set of $1000 \mathrm{~g}$ of ashuddha Jayapala seeds without removing the radicle.

\section{Analytical study}

Analytical study was carried out at S. D. M. Research centre of Ayurveda and Allied sciences, Udupi, Karnataka, India.

\section{Procedure of Croton oil estimation}

$5 \mathrm{~g}$ of the sample weighed in a thimble and placed it in a Soxhlet fitted with a condenser. $90 \mathrm{ml}$ of petroleum ether (B.P. $40-60^{\circ} \mathrm{C}$ ) was taken in $150 \mathrm{ml} \mathrm{RB}$ flask and boiled for 6 hours. The extract was taken in pre-weighed round bottom flask and petroleum ether was evaporated on a water bath. Residual traces of petroleum ether were removed by vacuum pump. Constant weight of the fat was taken $^{3}$. 


\section{Chromatography}

TLC of Jayapala seeds before and after shodhana

\section{Sample details}

- Track 1- Plain milk,

- Track 2- Jayapala with radicle,

- Track 3- Milk used for purifying Jayapala with radicle,

- Track 4- Jayapala with radical after swedana,

- Track 5- Jayapala with radicle after dying,

- Track 6- Jayapala without radicle after swedana,

- Track 7- Milk used for purifying Jayapala without radicle,

- Track 8- Jayapala without radicle after drying,

- Track 9- Radicle ${ }^{4}$

\section{Methodology}

\section{Extraction of milk}

Fifty ml of plain milk and the milk used for purification was diluted with $50 \mathrm{ml}$ of water and then extracted with $50 \mathrm{ml}$ of chloroform in separating funnel; the chloroform soluble portion was evaporated to dryness. Residue dissolved in $10 \mathrm{ml}$ of chloroform.

\section{Extraction of Jayapala}

One gram of test Jayapala samples were extracted with 10 $\mathrm{ml}$ of chloroform by cold percolation for $24 \mathrm{~h}$. The extract made up to $10 \mathrm{ml}$.

\section{TLC}

Five $\mu$ of the above samples were applied on a pre coated silica gel F 254 on aluminium plates to a band width of 8 $\mathrm{mm}$ using Linomat 5 TLC applicator. The plate was developed in Toluene - Ethyl acetate (6: 1) and the developed plate was visualized under UV 254 and 366 $\mathrm{nm}$, and after derivatization in vanillin-sulphuric acid spray reagent in CAMAG Photo documentation chamber.

\section{Detection of alkaloids}

Five $\mu 1$ of the above samples were applied on a pre coated silica gel F 254 on aluminium plates to a band width of 8 $\mathrm{mm}$ using Linomat 5 TLC applicator. The plate was developed in Toluene - Ethyl acetate (6: 1). The plate was derivatized with Dragendorff's reagent followed by $10 \%$ sodium nitrite.

\section{OBSERVATION AND RESULTS \\ Pharmaceutical study}

Seed coat of Jayapala was hard and found difficult to remove it, hence it was soaked in water and dried in shade to facilitate easy removal. Slight irritation to nose was appreciated while removing the seed coat and radicle. During swedana procedure the colour of milk gradually turned to light brownish and it created sweet but nauseating odour. After swedana procedure the seeds were oily to touch and creamish white in colour. The same colour was maintained during and after grinding. As the seeds were slippery, grinding the seeds was found difficult. Drying by applying the paste on new earthen plates under sun light changed the colour of the paste in to black. Earthen plates colour also found to be changed to dark brown and became oily after removal of dried paste of Jayapala.

Table 1: Results of pharmaceutical study

\begin{tabular}{|c|c|c|c|}
\hline $\begin{array}{l}\text { S. } \\
\text { No. }\end{array}$ & & $\begin{array}{c}\text { Method } \\
1 \\
\end{array}$ & $\begin{array}{c}\text { Method } \\
2 \\
\end{array}$ \\
\hline 1 & Weight of ashuddha Jayapala & $1000 \mathrm{~g}$ & $1000 \mathrm{~g}$ \\
\hline 2 & $\begin{array}{l}\text { Weight after removing seed } \\
\text { coat and radicle / without } \\
\text { radicle }\end{array}$ & $630 \mathrm{~g}$ & $670 \mathrm{~g}$ \\
\hline 3 & Weight of seeds after swedana & $650 \mathrm{~g}$ & $700 \mathrm{~g}$ \\
\hline 4 & Weight of after grinding & $640 \mathrm{~g}$ & $680 \mathrm{~g}$ \\
\hline 5 & $\begin{array}{l}\text { Weight of shuddha Jayapala } \\
\text { after complete drying }\end{array}$ & $400 \mathrm{~g}$ & $550 \mathrm{~g}$ \\
\hline 6 & Total loss & $600 \mathrm{~g}$ & $450 \mathrm{~g}$ \\
\hline 7 & $\%$ of loss & $60 \%$ & $45 \%$ \\
\hline
\end{tabular}

Table 2: Results of Croton oil estimation

\begin{tabular}{|c|c|}
\hline Sample & \% w/w of Croton oil \\
\hline Raw drug & 32.187 \\
\hline Drug with radicle after swedana & 32.2 \\
\hline Drug with radicle after drying & 33.72 \\
\hline $\begin{array}{c}\text { Drug without radicle after } \\
\text { swedana }\end{array}$ & 41.08 \\
\hline Drug without radicle after drying & 33.68 \\
\hline
\end{tabular}

Table 3: $R_{\mathrm{f}}$ values at UV 254

\begin{tabular}{|c|c|c|c|c|c|c|c|c|c|}
\hline & Trk 1 & Trk 2 & Trk 3 & Trk 4 & Trk 5 & Trk 6 & Trk 7 & Trk 8 & Trk 9 \\
\hline 0.34 & - & + & - & + & + & + & - & - & - \\
\hline 0.43 & + & - & - & - & - & - & - & - & - \\
\hline 0.47 & - & + & - & + & + & + & - & + & + \\
\hline 0.56 & + & + & - & + & + & + & + & + & - \\
\hline 0.68 & + & - & - & - & - & - & - & - & - \\
\hline 0.83 & - & - & - & - & - & - & + & - & - \\
\hline 0.87 & - & - & - & - & - & - & - & + & + \\
\hline 0.94 & + & - & + & + & + & + & + & + & + \\
\hline
\end{tabular}

Table 4: $\mathbf{R}_{\mathrm{f}}$ values at UV 366

\begin{tabular}{|c|c|c|c|c|c|c|c|c|c|}
\hline & Trk 1 & Trk 2 & Trk 3 & Trk 4 & Trk 5 & Trk 6 & Trk 7 & Trk 8 & Trk 9 \\
\hline 0.51 & + & + & + & + & + & + & + & + & + \\
\hline
\end{tabular}


Sujatha Ket al / Int. J. Res. Ayurveda Pharm. 4(6), Nov - Dec 2013

Table 5: $\mathbf{R}_{\mathrm{f}}$ values after derivatization with vanillin-sulphuric acid

\begin{tabular}{|c|c|c|c|c|c|c|c|c|c|}
\hline & Trk 1 & Trk 2 & Trk 3 & Trk 4 & Trk 5 & Trk 6 & Trk 7 & Trk 8 & Trk 9 \\
\hline 0.19 & - & - & - & - & - & - & + & - & - \\
\hline 0.21 & - & + & + & - & - & - & - & - & - \\
\hline 0.24 & + & + & + & - & + & + & - & + & + \\
\hline 0.28 & + & - & + & + & - & - & - & - & - \\
\hline 0.37 & - & + & - & + & + & + & + & + & + \\
\hline 0.41 & + & - & - & - & - & - & - & - & - \\
\hline 0.46 & - & + & - & - & - & - & - & - & - \\
\hline 0.48 & - & - & + & + & + & + & + & + & + \\
\hline 0.53 & + & + & - & - & - & - & - & - & - \\
\hline 0.57 & - & + & - & + & + & + & - & - & - \\
\hline 0.8 & - & - & - & - & + & - & - & + & - \\
\hline 0.89 & - & - & + & - & - & - & - & - & - \\
\hline 0.93 & + & + & - & + & + & + & + & + & + \\
\hline
\end{tabular}

Table 6: $R_{f}$ values after derivatization with Dragendorff's reagent

\begin{tabular}{|c|c|c|c|c|c|c|c|c|c|}
\hline & Trk 1 & Trk 2 & Trk 3 & Trk 4 & Trk 5 & Trk 6 & Trk 7 & Trk 8 & Trk 9 \\
\hline 0.45 & - & + & - & + & + & + & + & + & + \\
\hline 0.54 & - & + & - & + & + & + & + & - & - \\
\hline 0.69 & - & - & + & - & - & - & - & - & - \\
\hline 0.8 & + & + & - & - & - & - & - & - & - \\
\hline
\end{tabular}

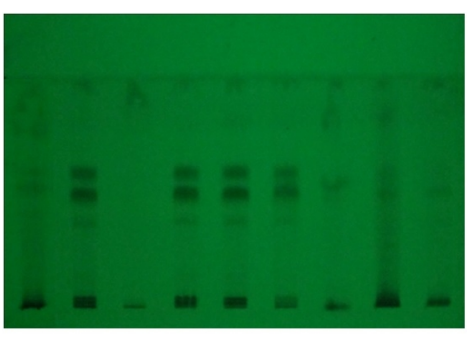

Photo Plate 1: TLC Photo documentation of Jayapala (5 $\mu$ l) UV 254

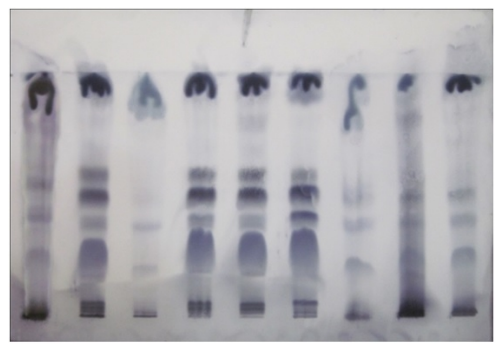

Photo Plate 3: After derivatization with vanillin-sulphuric acid

TLC fingerprint of Jayapala before and after shodhana along with the ingredients used for shodhana was obtained. On densitometric scan at $254 \mathrm{~nm}, 0.34$ peak was common in raw drug, after drying without radicle, after swedana with radical and after drying with radicle. 0.47 peak was common in raw drug, in milk, after swedana, after drying without radicle, and after swedana and drying with radical 0.56 peak was common in raw drug, milk, drug + milk both with and without radicle, in radicle, and after drying without radicle. 0.94 peak was common in milk, drug + milk both with and without radicle, after swedana both with and without radicle, in radicle and after drying with and without radicle. On densitometric scan at $366 \mathrm{~nm}, 0.51$ peaks were common in all the samples. After derivatisation with Vanillin - Sulphuric

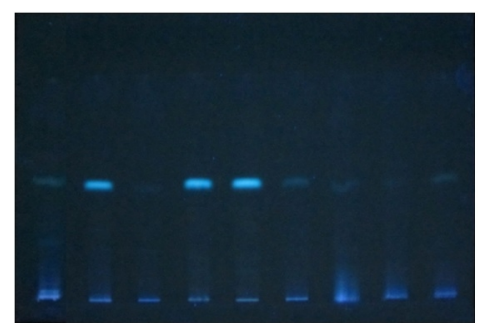

Photo Plate 2: TLC Photo documentation of Jayapala (5 $\mu$ l) UV 366

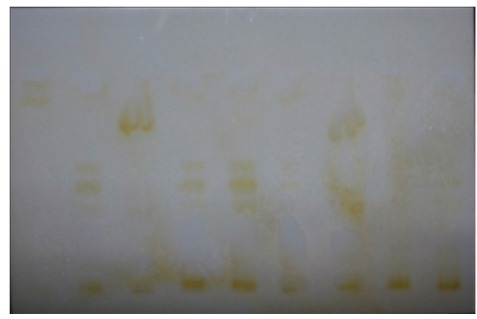

Photo Plate 4: After derivatization with dragendorff's reagent

acid 0.45 peak was common in raw drug, milk + drug without radicle, after swedana with and without radicle, after drying with and without radicle and in radicle. After derivatisation with Dragendorff's reagent, 0.21 peak was common in raw drug and milk + drug with radicle. 0.24 peak was common in raw drug, milk, milk + drug with and without radicle, after swedana without radicle, after drying with and without radicle. 0.28 peak was common in milk, milk + drug with radicle, after swedana with radicle.0.34 peak was common in raw drug, after swedana with and without radicle, in radicle, milk + drug without radicle, after drying with and without radicle. 0.48 peak was common in milk + drug with and without radicle, after swedana with radicle, in radicle, after drying with and without radicle. 0.53 peak was common in milk and 
raw drug ,0.57 peak was common in raw drug, after swedana with radicle, after drying with radical, 0.93 peak was common in milk, raw drug, after swedana with and without radicle, milk + drug without radicle, in radicle, after drying with and without radicle.

\section{DISCUSSION}

Jayapala shodhana was done as per the reference of Rasa tarangini ${ }^{2}$. Since the crotonalic acid present in Jayapala ${ }^{5}$ is an irritant to the skin, gloves were used while removing seed coat and radical. Milk is used for the swedana may be to reduce the tikshna and ushna guna of Jayapala. The colour change was noticed in milk and it can be attributed to the transfer of chemical constituents from the Jayapala seeds. After grinding, the paste of the Jayapala seeds was applied to the new earthen plates and dried in sunlight to remove the excess croton oil from it and thereby reducing the toxic effect of it. Absorption of croton oil by the new earthen plates was evident from the colour change of the plates and the colour change of the seeds to brown may be because of the loss of croton oil and drying. Weight loss was observed out of $1000 \mathrm{~g}$ of Raw Jayapala by the removal of seed coat, with and without radicle. Weight gain after swedana of seeds may be due to the absorption of milk. Because of adherence of grinded material to the mortar, loss was seen after grinding. After complete drying, maximum weight loss was observed may be due to the loss of croton oil and the moisture content in it. Croton oil \% was assessed in the raw drug, after swedana in milk and after complete drying of the Jayapala seeds with and without radicle. No marked difference was found in the croton oil \% in the samples with and without radicle. But in comparison to raw drug, slight increase in the oil \% was observed after shodhana may be because of the loss of moisture content in the drug which results in increase in the concentration of the oil. TLC of Jayapala before and after shodhana with and without radicle was done. The result showed that some of the peaks present in milk and the drug after shodhana was common indicating the addition of components of milk to Jayapala. Some common peaks were also found in raw Jayapala and the milk used for swedana suggesting that the components have transferred into the milk from raw drug. In comparison with the milk, drug after shodhana with and without radicle, more peaks of milk were common in the Jayapala after shodhana without radicle. This indicates
Shodhana process may get hindered in the presence of radicle as mentioned in the classics. The crotonoliec acid, main chemical constituent of the drug Jayapala occurs in free state and in combination as a glyceride. The glyceride does not possess poisonous properties, but the free acid acts as a powerful irritant to the skin and as a purgative in the intestines ${ }^{6}$. When seeds are subjected to swedana with the milk, the free crotonoliec acid may get bound with fatty acids of milk resulting in therapeutic property exhibition rather than poisonous effect and milk may also help in reducing the teekshna and ushna guna of Jayapala seeds ${ }^{7,8}$ by its mridu and sheetha properties.

\section{CONCLUSION}

Shodhana is a samskara adopted to visha dravys to reduce the toxicity of the drug and bringing about the therapeutic action. The procedure has to be adopted as per the reference since the analytical study showed significant changes in the shodhana of Jayapala with and without radicle before and after shodhana.

\section{REFERENCES}

1. Sharma Sadananda. Rasa Tarangini, Rasavijnana Hindi commentary, $11^{\text {th }}$ edition, Motilal Banarasidas Publications, New Delhi, Taranga 24/163; 2004. p. 675.

2. Sharma Sadananda. Rasa Tarangini, Rasavijnana Hindi commentary, $11^{\text {th }}$ edition, Motilal Banarasidas Publications, New Delhi, Taranga 24/315-317; 2004. p.705

3. Government of India, Ministry of Health and Family welfare, Department of Indian systems of medicine and Homeopathy. The Ayurvedic Pharmacopoeia of India, Part I, Volume III, $1^{\text {st }}$ edition. New Delhi: The Controller of Publications, Civil Lines; p. 235.

4. Government of India, Ministry of Health and Family welfare, Department of Indian systems of medicine and Homeopathy. The Ayurvedic Pharmacopoeia of India, Part I, Volume III, $1^{\text {st }}$ edition. New Delhi: The Controller of Publications, Civil Lines; p. 239-240.

5. Bhavamishra, Bhavaprakasha, Vidyotini hindi commentary, Chaukambha Sanskrit Bhavan, Varanasi, Volume I, Guduchyadi varga; 2010. p. 401

6. Nadkarni KM. Indian Materia Medica. Vol-I. Mumbai: Popular Prakashan Private Limited; 2010. p. 396

7. Agnivesha. Charaka Samhita, Ayurveda Dipika commentary. Edited by Acharya Yadavji Trikamji. Chaukhamba Oreintalia, Varanasi, Kalpasthana 12/6; 2011. p. 165.

8. Bhavamishra, Bhavaprakasha, Vidyotini hindi commentary, Chaukambha Sanskrit Bhavan, Varanasi, Volume I, Guduchyadi varga; 2010. p. 402

\section{Cite this article as:}

Sujatha K, Revanasiddappa S. Sarashetti, Swetha S. Analytical study on shodhana of Jayapala. Int. J. Res. Ayurveda Pharm. 2013;4(6):805-808 http://dx.doi.org/10.7897/2277-4343.04605 